\title{
O Coletivo Participativo na Problematização da Qualidade do Atendimento À Saúde
}

\author{
Levorato, Cleice Daiana; Ferreira, Maria Flávia Frajácomo; Martins, Juliana; Banov, \\ Marcos Carraro; Pellicani, Ariane Damasceno; Lanza, Ana Luíza; Canelada, Haline \\ Fernanda
}

Hospital Estadual Américo Brasiliense — cleicelevorato@yahoo.com.br

INTRODUÇÃO: Disposição centralizadora do poder, fragmentação do trabalho, baixa comunicação e insatisfação dos trabalhadores que não vislumbram os resultados de suas ações, são algumas das características do tradicional em gestão dos serviços de atendimento à saúde. um hospital, de média complexidade, no interior do estado de São Paulo, baseado em um modelo organizativo na gestão por processos e espaços coletivos de participação, desenvolve, desde 2010, o Grupo de Trabalho (GT), no qual a pauta de discussão são os processos de trabalho cotidianos. OBJETIVOS: Discutir e analisar problemas que entravam o funcionamento do serviço com vistas a manutenção e melhoria da qualidade do serviço prestado; Valorizar o trabalhador através da sua participação no processo de tomada de decisão. METODOLOGIA: É operacionalizado através do método da roda de discussão, com representantes das diversas áreas que compõem o processo de trabalho cotidiano e um presidente e vice-presidente para mediar as discussões, fomentadas através de acordos entre essa coletividade. Os assuntos são encaminhados pelos próprios membros a partir de situações do contexto em que se encontram e demandas das equipes. As reuniões são mensais, com horário, data e local fixo, com duração de uma hora e 30min. o conteúdo é documentado em ata e socializado na intranet. Mensalmente, o presidente e vice-presidente se reúnem com a Diretoria para discutirem as sugestões levantadas e a possibilidade de viabilização. RESULTADOS: em termos quantitativos na gestão do GT dos anos de 2010/2011 discutiram-se 111 assuntos, em 20111/2012: 71 e em 2012/2013: 31, demonstrando um refinamento dos processos de trabalho. na gestão 2012/2013, do total dos assuntos, 27 foram resolvidos pelo próprio GT e quatro foram encaminhados para Diretoria, com aprovação das sugestões do grupo. Estas mensurações foram dadas através de dois indicadores, os quais revelam o grau de autonomia e governabilidade do GT, que na última gestão demonstraram: 1) índice de resolutividade do GT: número de assuntos discutidos dividido pelo total de encaminhados, obtendo um valor de $86 \%$; 2 ) índice de resolutividade do GT frente a Diretoria: número de sugestões aceitas pela Diretoria dividido pelo total de assuntos encaminhados para a Diretoria, com um resultado de 100\%. Qualitativamente, têm-se a democratização das relações de trabalho com produção de sentido para quem operacionaliza a assistência, a diminuição das resistências a partir do momento em que a participação do colaborador promove a compreensão dos motivos de possíveis alterações nos processos de trabalho, ou seja, menor resistência e maiores entendimentos e a valorização do trabalhador quando este se sente partícipe, ao sugerir, discutir e conhecer, minimamente, os problemas que entravam a assistência. CONCLUSÃO: o GT permite o coletivo, o exercício da grupalidade e potencializa ações da atenção e da gestão, estas indissociáveis pela ótica da Política Nacional de Humanização.

Levorato, Cleice Daiana; Ferreira, Maria Flávia Frajácomo; Martins, Juliana; Banov, Marcos Carraro; Pellicani, Ariane Damasceno; Lanza, Ana Luíza; Canelada, Haline Fernanda. O Coletivo Participativo na Problematização da Qualidade do Atendimento À Saúde. In: Anais do Congresso Internacional de Humanidades \& Humanização em Saúde [= Blucher Medical Proceedings, num.2, vol.1]. São Paulo: Editora Blucher, 2014. ISSN 2357-7282

DOI 10.5151/medpro-cihhs-10322 